\author{
Nataliia Ilchenko \\ Doctor of Economic Science, Associate Professor, Head of the Trade Entrepreneurship and Logistic Department, \\ Kyiv National University of Trade and Economics, Ukraine \\ E-mail: n.ilchenko@knute.edu.ua \\ ORCID:0000-0003-4052-571X \\ Olha Freiuk \\ Postgraduate, Assistant of the Trade Entrepreneurship and Logistic Department, \\ Kyiv National University of Trade and Economics, Ukraine \\ E-mail: o.freyuk@knute.edu.ua \\ ORCID:0000-0002-4003-6927
}

\title{
Evolution of logistics management concepts in e-commerce
}

\begin{abstract}
In modern conditions, taking into account the rapid development of Internet technologies, e-commerce increases sales worldwide and has already been formed as a separate sector of the economy. One of the most significant changes that trade is currently undergoing is the progressive development and introduction of a remote way of selling goods. The growing popularity of implementing of the latest sales methods by the trade enterprises requires new approaches to the organization of supply of goods, ensuring their timely delivery and achieving the appropriate level of quality of customer service.

In developed countries, logistics is the driving force behind the changes in e-commerce enterprises that have developed significantly over the past 40 years. The precondition for the active development of logistics through the remote sale of goods was the emergence of electronic money in 1980-1990. At the same time, the first logistics companies appeared in the United States, the concept of "outsourcing" was introduced and distribution centers were formed.
\end{abstract}

The change of the traditional paradigm in trade to customer orientation, "pull system", gave impetus to changes in the management system of logistics flows. Thus, in 1992, a new concept of ECR (Efficient Consumer Response - economic relations with customers), which focused primarily on optimizing distribution channels and reducing costs not related to the process of creating valu, appeared. So, as for now, the question about the study of the evolution of logistics management in e-commerce arises.

The article investigates the formation of the conceptual foundations of logistics management of the enterprise taking into account the transformation of e-commerce.

\author{
Keywords \\ logistics, management, \\ e-commerce, supply \\ chain management, \\ evolution of logistics \\ management
}

JEL: M210

\section{Statement of the problem}

The development of e-commerce and increasing consumer demand for online shopping, puts before the company a serious logistical task to satisfy the consumer so that he receives the goods desirable: in 5 minutes; in eco-packaging; received the goods in a convenient way; with option of choice of favorite payment way, and return of the goods, if something does not work - quickly. The above tasks are presented to the logistics department, which is directly responsible for their solution. It should be considered that the organization of the logistics activities of the e-commerce company performs a cross-functional task, over time, these tasks only expand. Examining the approaches of scientists, 
we can say that there is not unanimous version of the evolution of logistics management.

\section{Latest scientific progress and publications review}

European as well as American scholars usually use the concept of supply chain management when talking about logistics management. Based on the booming E-commerce, logistics and supply chain management (LSCM) has been greatly influenced when we are now already overwhelmed by its successes in both developed and emerging economies :Yu, Y., Wang, X., Zhong, R.Y. and Huang, G.Q.[1]. The last five years one of the biggest disruptions in traditional retailing for a generation has taken place: Mena, C. and Bourlakis, M. [2], Saghiri, S.S., Bernon, M., Bourlakis, M. and Wilding, R. [3]. According to scientists, the evolution of logistics management cannot exist without the development of Internet technology.

\section{Purpose of the Research}

The purpose of the study is to analyze the evolutionary processes of the concept of logistics management, taking into account trends in the development of e-commerce, which will reveal the close relationship between these two activities.

\section{Main Material}

Global B2C e-commerce turnover reached over $\$ 2$ trillion in 2019. B2C e-commerce revenues rose to about more than 2 trillion USD in 2019. It is interesting to see how this revenue was distributed across the various regions of the world. It is astonishing that Asia/Oceania leads the list here with $44 \%$ of global sales generated in the region. That could occur, of course, through the driving force of China. The two following largest e-commerce regions are North America (26\%) and Europe (22\%) [4].According to the Ecommerce Foundation report, $72 \%$ of Europeans shop online. The United Kingdom counts the most online shoppers at $87 \%$. Germany (83\%) and France (76\%) are close behind. Italy, on the other hand, is far behind with $48 \%$ of its population shopping online. European shoppers spent an average of 1,715 USD online in 2019 [4].

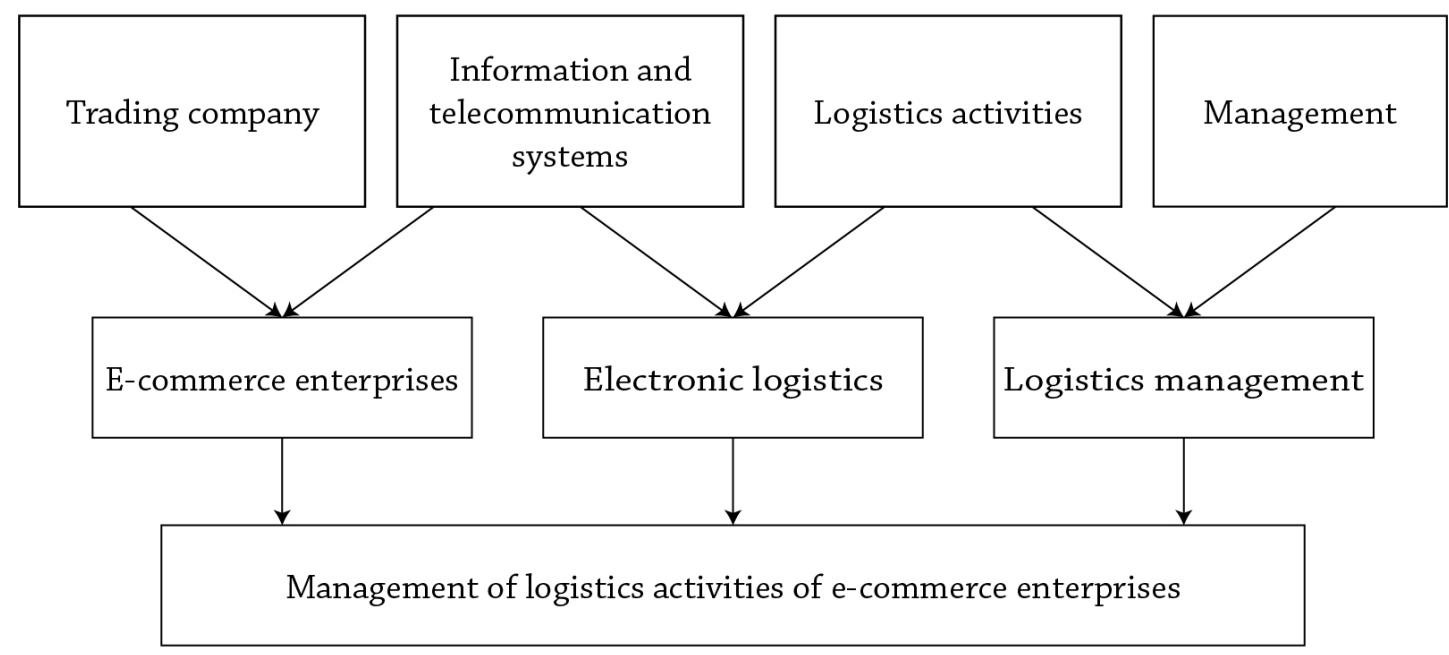

Figure 1 Diagram of the relationship of concepts related to the management of logistics activities in e-commerce Source: constructed by the authors

The figure shows that, management of logistics activities of e-commerce enterprises consists mainly of three part: E-commerce companies, electronic logistics and logistics management.

Before considering directly the evolution of concepts, it would be appropriate to consider the stages of formation of logistics activities in parallel with the development of trade (Table 1 ).

The technological advancements are not only building up a driving force for the entire logistics and e-commerce sector but also are transforming the way of a better living. These interconnected supply chains are letting businesses to build their online presence and outreach their products to different parts of the world. By collaborating different fields like transport, storage, and management, these logistics are providing service across the globe. There are a lot of latest trends are 
coming in into this sector.

The development and accessibility of interaction of supply chain participants remotely led to changes in logistics concepts.

Consider the concept in terms of two decades (Table 2).

TABLE 1 Stages of development of logistics activity of the e-commerce enterprise

\begin{tabular}{|c|c|c|}
\hline Terms & Trade activity & Logistics activity \\
\hline 2000-2010 & Development of e-commerce & $\begin{array}{l}\text { Transformation of distribution centers } \\
\text { into fulfilment. Electronic logistics }\end{array}$ \\
\hline 2010-2016 & $\begin{array}{l}\text { Development of mobile commerce, voice } \\
\text { commerce, television commerce, universal } \\
\text { commerce, digital commerce }\end{array}$ & $\begin{array}{l}\text { Digitalization of logistics } \\
\text { Fulfillment center in mega-sizes from } 50 \\
\text { thousand sq.m to } 90 \text { thousand sq.m }\end{array}$ \\
\hline 2017-2025 & $\begin{array}{l}\text { The active development of "commerce" or } \\
\text { reverse trade is the sale of second-hand } \\
\text { goods. Using artificial intelligence to reduce } \\
\text { inventory. Development of 3D technologies } \\
\text { for personalization of purchase. Engaging } \\
\text { of large retailers and the main owners of } \\
\text { commercial real estate (physical stores) in } \\
\text { online trade }\end{array}$ & $\begin{array}{l}\text { Robotic warehouse } \\
\text { Use of artificial intelligence in logistics } \\
\text { activities. Drones, unmanned vehicles and } \\
\text { delivery ships } \\
\text { Ecological logistics (reduction of } \\
\text { emissions from transport, use of eco- } \\
\text { packaging materials) }\end{array}$ \\
\hline
\end{tabular}

Source: completed by the data from [5-7]

TABLE 2 Evolution of concepts of logistic activity of the e-commerce enterprise 2000-2010

\begin{tabular}{|c|c|c|}
\hline Terms & Logistics concept & The essence \\
\hline \multirow{5}{*}{ 2000-2010 } & $\begin{array}{l}\text { DDT - Demand driven } \\
\text { Techniques/ Logistics }\end{array}$ & Demand-oriented logistics \\
\hline & QR (Quick Response) & $\begin{array}{l}\text { The concept of "rapid response", the essence of which is } \\
\text { to assess demand in real time and as close as possible } \\
\text { to the end consumer }\end{array}$ \\
\hline & $\begin{array}{l}\text { CR (Continuous } \\
\text { Replenishment) }\end{array}$ & $\begin{array}{l}\text { Logistics technology "continuous replenishment", } \\
\text { designed to eliminate the need for orders for finished } \\
\text { products to replenish stocks. This technology is a } \\
\text { modification of QR }\end{array}$ \\
\hline & $\begin{array}{l}\text { AR (Automatic } \\
\text { Replenishment) }\end{array}$ & $\begin{array}{l}\text { Automatic replenishment of stocks - a program of } \\
\text { replenishment of insurance stocks, which allows you } \\
\text { to maximize sales for each product category. This } \\
\text { technology also reduces the costs of retailers associated } \\
\text { with the division of stocks and ensuring the reliability } \\
\text { of their replenishment. }\end{array}$ \\
\hline & $\begin{array}{l}\text { SCM (supply chain } \\
\text { management system), } \\
\text { modified, including for the } \\
\text { development of e-commerce) }\end{array}$ & $\begin{array}{l}\text { Ability to create unique competitive advantages } \\
\text { by combining customer values with product flows. } \\
\text { Formation of social responsibility supply chain } \\
\text { participants. The relevant issues of interaction between } \\
\text { the enterprise and the environment (ecology, society). } \\
\text { Formation of social responsibility in accordance with } \\
\text { the requirements of the target market }\end{array}$ \\
\hline
\end{tabular}

Source: completed by the data from [8-10]

Summarizing the above concepts from 2000 to 2010, the management of logistics activities of e-commerce developed in 3 vectors, namely, meeting demand, accelerating operations, automation of inventories and the beginning of the emphasis of management on social responsibility.

Over the next 10 years, we will see how closely each concept is closely linked to the development of Internet technology.

The concept of e-logistics is the most modern and aimed at connecting all participants in the supply chain in the online space. It shall increase the efficiency and speed of adaptation of logistics processes in real time in a harmonized information standard. 
TABLE 3 Evolution of concepts of logistic activity of the e-commerce enterprise since 2010

\begin{tabular}{|c|c|c|}
\hline Terms & Logistics concept & The essence \\
\hline \multirow{4}{*}{$\begin{array}{c}2010 \text { - until } \\
\text { now }\end{array}$} & $\begin{array}{l}\text { DCM (Demand Chain } \\
\text { Management) }\end{array}$ & $\begin{array}{l}\text { Aimed at ensuring the interaction of logistics (including } \\
\text { distribution) and marketing (including after-sales service) }\end{array}$ \\
\hline & $\begin{array}{l}\text { SSCM (Sustainable } \\
\text { Supply Chain } \\
\text { Management) }\end{array}$ & $\begin{array}{l}\text { Provides for the relationship between enterprises and the } \\
\text { environment in general, i.e. this concept builds the concept } \\
\text { of SCM in the direction of social responsibility of chain } \\
\text { participants and business ethics }\end{array}$ \\
\hline & E-logistics & $\begin{array}{l}\text { The concept that transforms new logistics into customer- } \\
\text { oriented technology by sharing data, providing information } \\
\text { and accurate statistics with customers in the supply chain. } \\
\text { E-logistics helps to solve new problems in the field of supply } \\
\text { chains. The main components of e-logistics are multi-channel } \\
\text { operations, cross-border tasks, inventory plan and inventory, } \\
\text { planning, evaluation and efficiency management }\end{array}$ \\
\hline & Digital twinning & $\begin{array}{l}\text { The concept is to model the system in real time, which provides } \\
\text { a virtual design of physical assets. It allows you to manage both } \\
\text { digital and physical assets as a whole. In the logistics industry, } \\
\text { the development of digital duplicates for complex infrastructure } \\
\text { supply chains, such as ports and large warehouses, is still at an } \\
\text { early stage. However, major ports around the world, including } \\
\text { Singapore and Rotterdam, are turning to digital duplicates to } \\
\text { design, plan and manage their operations. }\end{array}$ \\
\hline
\end{tabular}

Source: completed by the data from [8-10]

It is worth noting the study of another modern concept - the concept of "digital twinning", which is in the logistics sector under development, but the implementation of this concept will allow, for example, virtually model warehouses and forecast their activities in real-time by changing their parameters virtually, which will provide an opportunity to apply this model and quickly adapt to changes in the external environment. Every process that takes place on the object (model) and every element will be reflected in the digital mirror, ensuring a constant flow of operational data. The advantage of execution of the concept of "digital twinning "in the logistics activities of the company may be, for example, the ability to quickly identify inefficiencies in certain areas of cargo handling or maintenance problems before they affect the capacity in "real life". It is worth noting that the information to the "double" is collected from the maximum number of sources (software, sensors, etc.), it is necessary to have a high-speed Internet, and with the advent of $5 \mathrm{G}$, this model will work even more efficiently [9].

Therefore, on the basis of the conducted research we have defined stages and evolution of concepts of management of logistic activity of the enterprises including electronic trade and outlined the basic tendencies of their development.

High-quality management of logistics activities of the enterprise provides an opportunity to develop trends in e-commerce logistics. On our opinion, the most important trend is called "a better risk management" [11]. This type of trends of logistics and supply chain nowadays are bracing themselves up with proper disaster management. Thus different logistics operations are taking up better practices to improve their supply chain management and dealing better with all the risk factors [11]

Total digitization of the supply chain has not only improved the speed and dynamics but has also brought resiliency in the operations of these supply chain. Through this method, these logistics companies not only witnessed the performance graph and but also increased their market revenue. The field is vast and there are a lot of transformative solutions available. The digitization is helping them monitor their inventory, manage their warehouse stocks and also make detailed plans about the transport routes so that they don't have to spend on extra dead mileage [11].

The use of Artificial intelligence and using sAAs for managing supply chains are making the logistics targets much easier, and achievable. The robotics concept has already been implemented in the different supply chains. They are easy to operate and are pretty cost-effective and flexible. The process has gained popularity as the functionality of cloud computing came into the market. This technology allows different logistics business to 
stave off high fixing cost and helps in easy maintenance with timely upgrades and also looks after the infrastructure-related expenditures [11].

Also, in E-logistics social media platforms are used. This helps a lot of e-commerce and logistics to find a suitable way to coordinate with the customers. This is also useful when it comes to sharing business news, giving out information and working on customer feedback as early as possible.

One of the evolutionary features of the management of logistics activities of e-commerce is the constant acceleration of processes and reduction of time to perform operations, this applies directly to management. Thus, an

CHALLENGING
SUSTAINABLE

Figure 2 CRASH goal setting model

Source: constructed by the authors

e-commerce company, including due to the coronavirus crisis, need to attract tools for rapid goal-setting.

The authors have developed an adaptive version of goal setting, which can be used in conditions of uncertainty, due to its simplicity and speed. Based on the results of the study of uncertainty conditions that arose in 2020, we offer a new method of goal setting developed by us called "CRASH". Quite a provocative name in the conditions of force majeure is an anagram aimed at a quick check on the audacity and reality of the goals (. 3.4). The CRASH model will allow at the stage of planning the logistics activities of the e-commerce company to determine the feasibility of providing support for management decisions in real time and will determine the directions of development of logistics activities. The CRASH goal-setting model is deciphered as: $\mathrm{C}$ - challenging, $\mathrm{R}$ - reality, $\mathrm{A}$ actual - $\mathrm{S}$ - sustainable; $\mathrm{H}$ - harmonious.

We propose to consider an example of applying the model to improve the logistics system and to accelerate the speed of delivery of goods of an enterprise specializing in the sale of household appliances and electronics. The purpose of using the model in the verification of the purpose of the application of additional services offered by LLC "Glovo Ukraine" (Glovo) and LLC "ROCKET DELIVERY" (Raketa). Using the goal-setting model "CRASH", we demonstrate additional solutions that can be used by the company (Table 4).
Analyzing the services of delivery of goods by enterprise, for example, specializing in delivery from restaurants, grocery stores, the experience of drogerie companies (companies selling cosmetics and household chemicals) we can conclude that for e-commerce companies specializing in the sale of home appliances and electronics it is necessary to pay attention to the size (weight, size) of the delivered goods and the readiness to quickly form an order for the courier. E-commerce companies specializing in the sale of home appliances and electronics should form a range based on these two basic conditions, as well as take into account the availability of self-pickup points for couriers. We consider this area promising because the delivery services are also interested in meeting all the needs of consumers.

\section{Conclusions}

Based on the results of the study of the evolution of logistics concepts, we proposed to supplement their list of "Electronic Logistics" and "Digital Twinning", taking into account current trends in retail, and the scale of logistics activities that require professional guidance. To improve the efficiency of goal setting in the management of logistics activities, the authors proposed the CRASH model. This example showed that the model can be applied to the e-commerce enterprise, but can also be an effective tool in management in general. 
TABLE 4 Model CRASH for the e-commerce enterprise

\begin{tabular}{|c|c|c|c|}
\hline Model components & \multicolumn{3}{|c|}{ The goal } \\
\hline \multirow{2}{*}{ C - challenging } & \multicolumn{3}{|c|}{$\begin{array}{l}\text { Objective: to increase the availability of e-commerce to the consumer through } \\
\text { delivery services * through mobile add }\end{array}$} \\
\hline & $\begin{array}{l}\text { Clarifying questions to } \\
\text { meet the goal }\end{array}$ & \multicolumn{2}{|c|}{ Analysis of services } \\
\hline \multirow{15}{*}{$\mathbf{R}$ - reality } & \multirow{15}{*}{$\begin{array}{l}\text { Do these services exist in } \\
\text { Ukraine? } \\
\text { Are they in demand? } \\
\text { What are the conditions } \\
\text { for involving them in } \\
\text { cooperation? } \\
\text { Are there any restrictions } \\
\text { (dimensions, territory) in } \\
\text { their activities? }\end{array}$} & Glovo Ukraine LLC & $\begin{array}{l}\text { ROCKET DELIVERY } \\
\text { LLC }\end{array}$ \\
\hline & & \multicolumn{2}{|c|}{ Year of appearance on the Ukrainian market } \\
\hline & & 2018 & 2019 \\
\hline & & \multicolumn{2}{|c|}{$\begin{array}{l}\text { The percentage of service fees by the } \\
\text { company }\end{array}$} \\
\hline & & $30-40 \%$ & $30 \%$ without VAT \\
\hline & & \multicolumn{2}{|c|}{ Terms of involvement in cooperation } \\
\hline & & $\begin{array}{l}\text { 1. Preparation of the } \\
\text { order at the enterprise } \\
\text { optimally takes } 45 \\
\text { minutes }\end{array}$ & $\begin{array}{l}\text { 1. Location in a city } \\
\text { with a population of } \\
\text { over } 200 \text { thousand } \\
\text { people } \\
\text { 2. Preparation of the } \\
\text { order at the enterprise } \\
\text { optimally takes } 45 \\
\text { minutes }\end{array}$ \\
\hline & & \multicolumn{2}{|c|}{ Parcel dimensions } \\
\hline & & $\begin{array}{l}\text { Size:40x40x30 cm } \\
\text { Weight: } 9 \mathrm{~kg}\end{array}$ & Weight: up to $20 \mathrm{~kg}$ \\
\hline & & \multicolumn{2}{|c|}{ Territorial accessibility } \\
\hline & & $\begin{array}{l}22 \text { cities of Ukraine The } \\
\text { distance is NOT fixed }\end{array}$ & $\begin{array}{l}25 \text { cities of Ukraine, } \\
\text { including } 17 \text { regional } \\
\text { centres } \\
\text { Distance up to } 3.5 \mathrm{~km}\end{array}$ \\
\hline & & \multicolumn{2}{|c|}{ Delivery time } \\
\hline & & $\begin{array}{l}\text { Up to } 60 \text { minutes, } 8: \\
00-23: 00\end{array}$ & $\begin{array}{l}\text { Up to } 60 \text { minutes, } 8: \\
00-22: 00\end{array}$ \\
\hline & & Shippi & g cost \\
\hline & & $40+\mathrm{UAH}$ & 40-60 UAH \\
\hline \multirow{4}{*}{ A - actual } & \multirow{4}{*}{$\begin{array}{l}\text { How many consumers use } \\
\text { the service? }\end{array}$} & \multicolumn{2}{|c|}{ Number of application downloads } \\
\hline & & $\begin{array}{l}3 \text { million in Ukraine } \\
\text { (over } 10 \text { million } \\
\text { worldwide) }\end{array}$ & 2 million in Ukraine \\
\hline & & \multicolumn{2}{|c|}{ Number of partners } \\
\hline & & $3000-3500$ units & nearly 2000 units \\
\hline S - sustainable & $\begin{array}{l}\text { How stable are the } \\
\text { services? }\end{array}$ & \multicolumn{2}{|c|}{$\begin{array}{l}\text { An increase in the number of orders by an averag } \\
\text { of } 40 \% \text { during quarantine }\end{array}$} \\
\hline H - harmonious & $\begin{array}{l}\text { Terms of connection } \\
\text { of the service to the } \\
\text { site of the e-commerce } \\
\text { enterprise }\end{array}$ & \multicolumn{2}{|c|}{$\begin{array}{l}\text { Harmonization of partner software and } \\
\text { application }\end{array}$} \\
\hline
\end{tabular}

Source: completed by the data from [12-13] 


\section{References}

[1] Yu Y, Wang X, Zhong R Y, Huang G Q 2017 E-commerce logistics in supply chain management: Implementations and future perspective in furniture industry Industrial Management \& Data Systems 117(10) 2263-86 E-source: https://doi.org/10.1108/IMDS-09-2016-0398

[2] Mena C, Bourlakis M 2016 Retail logistics special issue International Journal of Physical Distribution \& Logistics Management 46(6/7)

[3] Saghiri S S, Bernon M, Bourlakis M, Wilding R 2018 Omni-channel logistics special issue International Journal of Physical Distribution \& Logistics Management 48(4) 362-4 E-source: https:// doi.org/10.1108/IJPDLM-05-2018-361

[4] E-source: https://blog.lengow.com/global-ecommerce-2019-report/

[5] Skitsko V I 2014 E-logistics as a component of modern business Business Inform 7 309-14 E-source: http://nbuv.gov.ua/UJRN/binf_2014_7_56 (in Ukrainian)

[6] TOP trends of e-commerce in 20202020 PaySpace Magazine Global E-source: https://psm7.com/uk/ e-commerce/top-trendov-elektronnoj-kommercii-v-2020-godu.html

[7] I, robot: how Amazon robotized warehouse works (photo report) 2018 E-source: https://rau.ua/ ecommerceuk/fotoreportazh-amazon/ (in Ukrainian)

[8] Kanagavalli G 2019 Logistics and E- Logistics Management: Benefits and Challenges International Journal of Recent Technology and Engineering (IJRTE) 4 E-source: URL:///C:/ Users/\%D0\%9E\%D0\%BB\%D1\%8C\%D0\%B3\%D0\%B0/Downloads/D7179118419.pdf

[9] "Digital twins" - an new level of supply chains development 2020 E-source: https://logist.fm/news/ cifrovi-dviyniki-noviy-riven-rozvitku-lancyugiv-postachannya (in Ukrainian)

[10] Uzialko A 2020 What Is B2B? E-source: https://www.businessnewsdaily.com/5000-what-is-b2b. html.https://envolveglobal.org/business-to-consumer-b2c/

[11] E-source: https://ithinklogistics.com/blog/evolution-of-e-commerce-logistics-supply-chainmanagement/

[12] To outer space: How Raketa service had entered competitive market and reached success 2020 E-source: https://rau.ua/novyni/novini-kompanij/yak-raketa-dosyagla-uspihu/ (in Ukrainian)

[13] Out for food. Thanks to what Glovo and Raketa has got rid of the competitors of delivery business and who is going to challenge them 2020 E-source: https://nv.ua/ukr/biz/markets/servisi-dostavki-yakglovo-i-raketa-vitisnili-konkurentiv-iz-rinku-novini-ukrajini-50096262.html (in Ukrainian)

[14] Courier delivery service Glovo sterted in Kropyvnyts'kyy 2020 E-source: https://uaspectr. com/2020/07/22/glovo-zapustyvsya-v-kropyvnytskomu/ (in Ukrainian) 